\title{
Bending and compression tests for PA 2200 parts obtained using Selective Laser Sintering method
}

\author{
Cristina Stefana Miron-Borzan ${ }^{1, *}$, Mircea Cristian Dudescu ${ }^{2}$, and Petru Berce ${ }^{1}$ \\ ${ }^{1}$ Technical University of Cluj-Napoca, Manufacturing Engineering Department, 400641B-dul Muncii, \\ no. 103-105, Cluj-Napoca, Romania \\ ${ }^{2}$ Technical University of Cluj-Napoca, Mechanical Engineering Department, 400641B-dul Muncii, \\ no. 103-105, Cluj-Napoca, Romania
}

\begin{abstract}
Craniofacial bone defects that produce morphological and functional disabilities can bring alteration of the quality of patient's life. For this reason, the collaboration between the field of medicine with engineering, lead to the manufacture of custom implants from biocompatible materials. In the last years it was shown that Additive Manufacturing methods are very helpful to achieve customized medical implants. All the customized implants made of biocompatible materials have to be tested for mechanical properties, in order to have the optimal characteristics for the area were will be used. This paper presents the results for bending and compression tests for a biocompatible material, PA 2200. The samples were achieved using Selective Laser Sintering method and were obtained with different laser power, starting with $4 \mathrm{~W}$. Maximum load, maximum stress, specific deformation and Young's modulus were analysed. The study showed that different mechanical properties can be obtained, depending on the laser power used. At bending tests, increasing values were obtained for the investigated parameters along with laser power increasing, but at compression tests a different trend was observed.
\end{abstract}

\section{Introduction}

A successful result for repairing of complex craniofacial bone defects depends on the defect size, the quality of the soft tissue covering the defect, and the choice of reconstructive method. The complex craniofacial skeleton is involved with various specific functions, such as protection of the brain and optic tracts, breathing, mastication, speech, and hearing $[1,2]$.For this reason is very important to know the forces and which are the required mechanical properties for the future implant that will take over all the forces from the area.

Recent advances in Computer-Aided Design and Computer-Aided Manufacturing have begun to revolutionize craniofacial surgery, which is frequently confronted with the reconstruction of challenging 3D anatomic structures. Additive Manufacturing technology, with widespread availability of high-resolution medical imaging, has allowed for the

*Corresponding author: borzan_cristina@ymail.com 
generation of contoured 3D prostheses for craniofacial reconstruction [2].Computer technology has moved forward with the advent of Additive Manufacturing techniques which allow both the production of models of the hard tissues and custom-made prostheses from computerised scanning data [3].

Selective Laser Sintering (SLS) is a manufacturing technique which enables the final product to be made directly and rapidly, without tooling or additional machining. For biomedical applications, SLS permits the fabrication of implants and scaffolds with complex geometry accurately and economically [4]. Selective Laser Sintering technique has been identified as a promising technique capable of building complex objects with predefined macro and microstructures [5].

In the last decade, the bio-medical industry was focused more and more on developing and exploiting of materials that are easy accepted by the human body [6].Polyamide is a biocompatible material that has a polar molecular structure $(\mathrm{CO}-\mathrm{NH}-)$ similar with the chemical structure of bone collagen and exhibits excellent mechanical properties [7].

Customized properties of parts manufactured using the Selective Laser Sintering process are achievable by variation of build parameters [8].

Static tensile test is a basic mechanical test originally designed to become the widespread and known testing method for evaluating the mechanical properties of materials [9]. But for a future cranial implant are very important the bending and compression tests, that can show the stresses in normal and accidental situations. These stresses are much closer to the real situation from the human body.

A testing sample can help to determine standard basic mechanical properties such as: tensile strength, yield strength, elastic modulus and Poisson's ratio [10].

In the literature there are few studies that reported the properties of cranial bone at bending tests. There are some researchers that presented the results at bending tests of a human bone. Hubbard in 1971 [11] and Delille in 2007 [12] presented the mechanical properties for an adult cranial bone. The infant cranial bone was analysed by other researchers: McPherson in 1980 [13], Margulies in 2000 [14], Jans in 2003 [15] and Coats in 2006 [16].

\section{Method and materials}

This paper is part of a larger research that is focused on the behaviour and properties of PA2200parts used for custom implants manufactured by selective laser sintering process.

The materials used: Polyamide PA 2200, on the basis of polyamide 12 (PA 12), a bio compatible material according to EN ISO 10993-1 and USP/level VI/121 ${ }^{\circ} \mathrm{C}$. The material was produced by the Electro Optical Systems - EOS GmbH, Munich, Germany, especially to be used for the EOS Laser Sintering Systems.

The technical characteristics of the material are: water absorption $100^{\circ} \mathrm{C}$, saturation in water: $1.93 \%$ (according with ISO 62 / DIN 53495), coefficient of linear thermal expansion: 1.09 x10-4 /K (according with ISO 11359 / DIN 53752-A), specific heat: 2.35 $\mathrm{J} / \mathrm{gK}$ (DIN 51005), thermal conductivity vertical to sintered layers: $0.144 \mathrm{~W} / \mathrm{mK}$ (DIN 52616).

The manufacturing process was Selective Laser Sintering, using a DTM Sinterstation 2000 System with a CO2 laser. The PA 2200 powder was brought layer by layer from the two powder suppliers on the working place using the roller and was heated to near the melting point with the help of the laser beam, which drawn the shape of the virtual model. Thus, the component particles were bonded one to others, solidifying into the shaped form drawn by beam. When a solid layer was obtained, the platform was moved down with an equal distance to the thickness of the following sintered layer. The powder was again 
spread and sintered in the form of a new layer. The previous layer, represented a support for the current layer of material.

The samples were achieved at temperature $170^{\circ} \mathrm{C}$, with the thickness of deposited layer - $100 \mu \mathrm{m}$, scan speed $-1257.3 \mathrm{~mm} / \mathrm{s}$ and laser power $4 \mathrm{~W}, 4.5 \mathrm{~W}, 6 \mathrm{~W}$.

Experimental researches were done in order to determine the mechanical properties of polyamide structures made of PA 2200 with different laser powers. It was manufactured sets of 5 samples for each laser power.

The samples were achieved starting with the 3D models (designed in SolidWorks 2013 software) according with SR EN ISO 178:2011 for bending tests and SR EN ISO 604:2004 for compression tests.

For bending and compression tests it was used a $10 \mathrm{kN}$ testing machine (INSTRON 3366).

Figure 1 shows a picture from the bending tests of specimens.

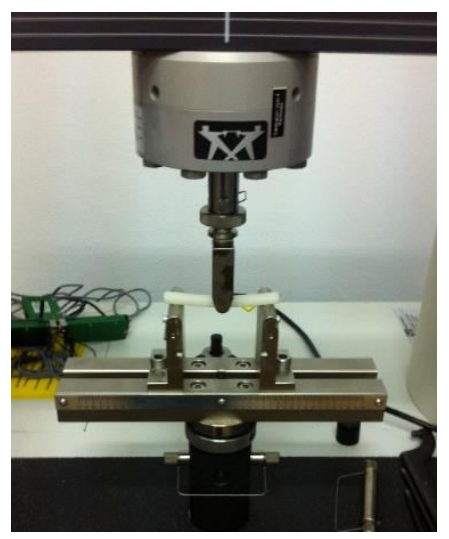

Fig. 1. Bend testing of specimens on Instron 3366 Machine.

\section{Results and discussions}

In tables 1, 2 and 3 are presented the mechanical properties obtained at the bending tests for PA 2200 samples obtained at $4 \mathrm{~W}, 4.5 \mathrm{~W}$ and $6 \mathrm{~W}$.For samples manufactured at $4 \mathrm{~W}$, analysing the results obtained for each characteristics, it was observed that the values were close to each other and were determined standard deviations 4.906 for maximum load, 3.098 for maximum stress and 77.464 for Young's modulus. However, the lowest values were recorded at the specimen No. 2 for all the analysed characteristics.

Table 1.The mechanical properties for PA 2200 specimens manufactured at $4 \mathrm{~W}$ at bending tests.

\begin{tabular}{|c|c|c|c|c|}
\hline Sample & $\begin{array}{c}\text { Maximum } \\
\text { Load [N] }\end{array}$ & $\begin{array}{c}\text { Maximum } \\
\text { Stress, } \\
{[\mathbf{M P a}]}\end{array}$ & $\begin{array}{c}\text { Specific Deformation, } \\
{[\mathbf{m m} / \mathbf{m m}]}\end{array}$ & $\begin{array}{c}\text { Young's } \\
\text { modulus, } \\
{[\mathbf{M P a}]}\end{array}$ \\
\hline 1 & 106.07 & 66.99 & 0.07 & 1703.77 \\
\hline 2 & 95.51 & 60.32 & 0.06 & 1535.13 \\
\hline 3 & 106.65 & 67.36 & 0.07 & 1689.14 \\
\hline 4 & 97.89 & 61.83 & 0.07 & 1558.41 \\
\hline 5 & 101.55 & 64.14 & 0.07 & 1582.58 \\
\hline $\begin{array}{c}\text { Mean } \\
\text { Value }\end{array}$ & $\mathbf{1 0 1 . 5 3}$ & $\mathbf{6 4 . 1 3}$ & $\mathbf{0 . 0 7}$ & $\mathbf{1 6 1 3 . 8 1}$ \\
\hline $\begin{array}{c}\text { Standard } \\
\text { Deviation }\end{array}$ & $\mathbf{4 . 9 0 6}$ & $\mathbf{3 . 0 9 8}$ & $\mathbf{0 . 0 0 4}$ & $\mathbf{7 7 . 4 6 4}$ \\
\hline
\end{tabular}


The same trend it was observed also in the case of PA 2200 speciments manufactured at $4.5 \mathrm{~W}$, minimum values for sample No. 2 were obtanied for all the anaysed characteristics. The values were aproximatelly close, with standard deviation 6.84 for maximum load, 4.32 for maximum stress, 0.01 for specific deformation and 82.68 for Young's modulus.

Table 2. The mechanical properties for PA 2200 specimens manufactured at $4.5 \mathrm{~W}$ at bending tests.

\begin{tabular}{|c|c|c|c|c|}
\hline Sample & $\begin{array}{c}\text { Maximum } \\
\text { Load [N] }\end{array}$ & $\begin{array}{c}\text { Maximum } \\
\text { Stress, [MPa] }\end{array}$ & $\begin{array}{c}\text { Specific } \\
\text { Deformation, } \\
{[\mathbf{m m} / \mathbf{m m}]}\end{array}$ & $\begin{array}{c}\text { Young's } \\
\text { modulus, } \\
{[\mathrm{MPa}]}\end{array}$ \\
\hline 1 & 105.45 & 66.60 & 0.07 & 1699.31 \\
\hline 2 & 89.53 & 56.55 & 0.06 & 1498.75 \\
\hline 3 & 99.75 & 63.00 & 0.08 & 1634.58 \\
\hline 4 & 104.25 & 65.84 & 0.08 & 1651.82 \\
\hline 5 & 105.87 & 66.87 & 0.08 & 1701.23 \\
\hline $\begin{array}{c}\text { Mean } \\
\text { Value }\end{array}$ & $\mathbf{1 0 0 . 9 7}$ & $\mathbf{6 3 . 7 7}$ & $\mathbf{0 . 0 7}$ & $\mathbf{1 6 3 7 . 1 4}$ \\
\hline $\begin{array}{c}\text { Standard } \\
\text { Deviation }\end{array}$ & $\mathbf{6 . 8 4}$ & $\mathbf{4 . 3 2}$ & $\mathbf{0 . 0 1}$ & $\mathbf{8 2 . 6 8}$ \\
\hline
\end{tabular}

Also for thesamples manufactured at $6 \mathrm{~W}$, the minimum values for maximum load, maximum stress and specific deformation were achieved for sample No 2, but in the case of specific deformation and Young's modulus, the values were superior to the values of sample No 1.

Table 3.The mechanical properties for PA 2200 specimens manufactured at $6 \mathrm{~W}$ at bending tests.

\begin{tabular}{|c|c|c|c|c|}
\hline Sample & $\begin{array}{c}\text { Maximum } \\
\text { Load [N] }\end{array}$ & $\begin{array}{c}\text { Maximum } \\
\text { Stress, [MPa] }\end{array}$ & $\begin{array}{c}\text { Specific } \\
\text { Deformation, } \\
{[\mathbf{m m} / \mathbf{m m}]}\end{array}$ & $\begin{array}{c}\text { Young's } \\
\text { modulus, } \\
{[\mathbf{M P a}]}\end{array}$ \\
\hline 1 & 126.58 & 72.44 & 0.08 & 1591.47 \\
\hline 2 & 124.64 & 71.98 & 0.08 & 1604.20 \\
\hline 3 & 130.90 & 76.44 & 0.08 & 1705.20 \\
\hline 4 & 126.10 & 74.95 & 0.08 & 1771.52 \\
\hline 5 & 126.76 & 71.78 & 0.08 & 1655.69 \\
\hline $\begin{array}{c}\text { Mean } \\
\text { Value }\end{array}$ & $\mathbf{1 2 7 . 0 0}$ & $\mathbf{7 3 . 5 2}$ & $\mathbf{0 . 0 8}$ & $\mathbf{1 6 6 5 . 6 2}$ \\
\hline $\begin{array}{c}\text { Standard } \\
\text { Deviation }\end{array}$ & $\mathbf{2 . 3 3 6}$ & $\mathbf{2 . 0 6 8}$ & $\mathbf{0 . 0 0 1}$ & $\mathbf{7 4 . 4 1 6}$ \\
\hline
\end{tabular}

Analysing the mean values obtained at bending tests, for each sets of samples manufactured at $4 \mathrm{~W}, 4.5 \mathrm{~W}$, respectively at $6 \mathrm{~W}$, it was observed an increasing of the values for maximum loads and stresses, once the laser power is higher (from $4.5 \mathrm{~W}$ to $6 \mathrm{~W}$ ). The specific deformation and the Young's modulus is also increasing with the higher laser power used (from $0.06 \mathrm{~mm} / \mathrm{mm}$ at $4 \mathrm{~W}$ to $0.08 \mathrm{~mm} / \mathrm{mm}$ at $6 \mathrm{~W}$ for specific deformation and from $1613 \mathrm{MPa}$ to $1665 \mathrm{MPa}$ for Young's modulus). 

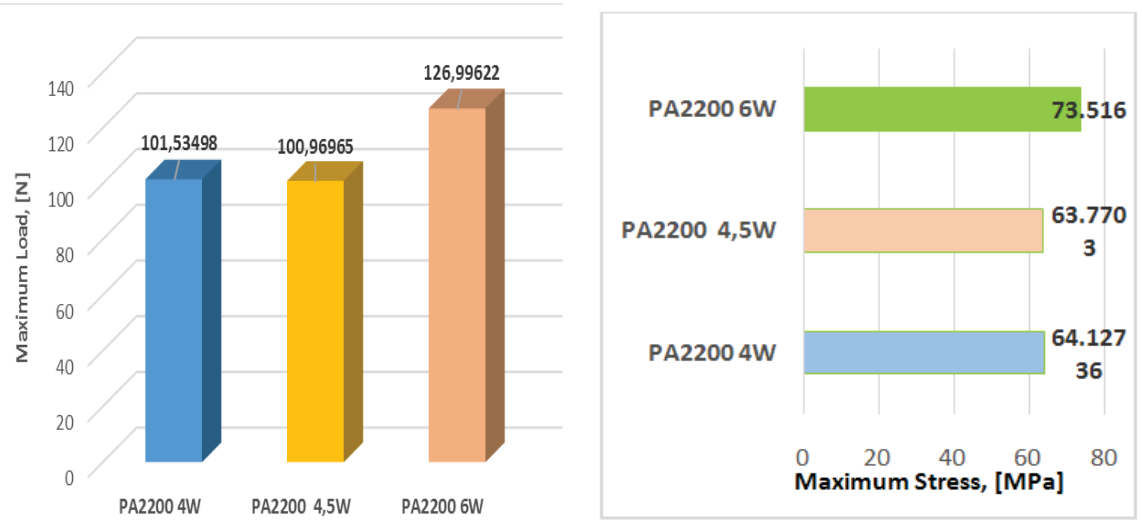

Fig. 2. Mean values of the maximum load and maximum stress for PA 2200 samples at bending tests.

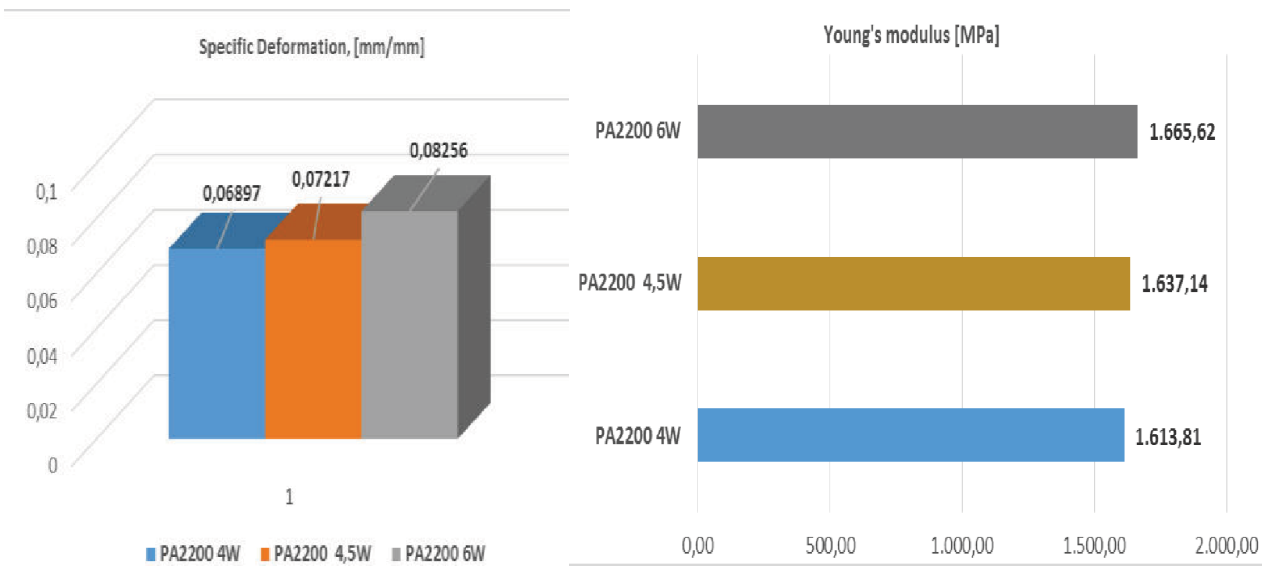

Fig. 3. Mean values of the specific deformation and Young's modulus for PA 2200 samples at bending tests.

In tables 4,5 and 6 are presented the mechanical properties obtained at the compression tests for PA 2200 samples obtained at $4 \mathrm{~W}, 4.5 \mathrm{~W}, 6 \mathrm{~W}$.

Table 4. The mechanical properties for compression tests for PA 2200 specimens at $4 \mathrm{~W}$.

\begin{tabular}{|c|c|c|c|c|}
\hline Sample & $\begin{array}{c}\text { Maximum } \\
\text { Load [N] }\end{array}$ & $\begin{array}{c}\text { Maximum } \\
\text { Stress, [MPa] }\end{array}$ & $\begin{array}{c}\text { Specific } \\
\text { Deformation, } \\
{[\mathbf{m m} / \mathbf{m m}]}\end{array}$ & $\begin{array}{c}\text { Young's } \\
\text { modulus, } \\
{[\mathbf{M P a}]}\end{array}$ \\
\hline 1 & 5634.71 & 62.61 & 0.25 & 1143.77 \\
\hline 2 & 4968.28 & 55.20 & 0.14 & 1230.86 \\
\hline 3 & 5413.65 & 60.15 & 0.20 & 1169.63 \\
\hline 4 & 5214.72 & 57.94 & 0.17 & 1266.19 \\
\hline 5 & 5404.21 & 60.05 & 0.16 & 1317.22 \\
\hline 6 & 5288.63 & 58.76 & 0.16 & 1282.25 \\
\hline $\begin{array}{c}\text { Mean } \\
\text { Value }\end{array}$ & $\mathbf{5 3 2 0 . 7 0}$ & $\mathbf{5 9 . 1 2}$ & $\mathbf{0 . 1 8}$ & $\mathbf{1 2 3 4 . 9 9}$ \\
\hline $\begin{array}{c}\text { Standard } \\
\text { Deviation }\end{array}$ & $\mathbf{2 2 3 . 9 1}$ & $\mathbf{2 . 4 9}$ & $\mathbf{0 . 0 4}$ & $\mathbf{6 7 . 2 0}$ \\
\hline
\end{tabular}


Table 5. The mechanical propertiesfor compression tests for PA 2200 specimens at $4.5 \mathrm{~W}$.

\begin{tabular}{|c|c|c|c|c|}
\hline Sample & $\begin{array}{c}\text { Maximum } \\
\text { Load [N] }\end{array}$ & $\begin{array}{c}\text { Maximum } \\
\text { Stress, [MPa] }\end{array}$ & $\begin{array}{c}\text { Specific } \\
\text { Deformation, } \\
{[\mathbf{m m} / \mathbf{m m}]}\end{array}$ & $\begin{array}{c}\text { Young's } \\
\text { modulus, } \\
{[\mathbf{M P a}]}\end{array}$ \\
\hline 1 & 5452.54 & 60.58 & 0.12 & 1310.96 \\
\hline 2 & 5522.72 & 61.36 & 0.12 & 1298.45 \\
\hline 3 & 5151.48 & 57.24 & 0.16 & 1265.06 \\
\hline 4 & 5560.66 & 61.79 & 0.14 & 1297.22 \\
\hline 5 & 6080.95 & 67.57 & 0.23 & 1325.37 \\
\hline 6 & 5361.26 & 59.57 & 0.11 & 1287.26 \\
\hline $\begin{array}{c}\text { Mean } \\
\text { Value }\end{array}$ & $\mathbf{5 5 2 1 . 6 0}$ & $\mathbf{6 1 . 3 5}$ & $\mathbf{0 . 1 5}$ & $\mathbf{1 2 9 7 . 3 9}$ \\
\hline $\begin{array}{c}\text { Standard } \\
\text { Deviation }\end{array}$ & $\mathbf{3 1 0 . 4 4}$ & $\mathbf{3 . 4 5}$ & $\mathbf{0 . 0 5}$ & $\mathbf{2 0 . 5 7}$ \\
\hline
\end{tabular}

Table 6. The mechanical properties for compression tests forPA 2200 specimens at $6 \mathrm{~W}$.

\begin{tabular}{|c|c|c|c|c|}
\hline Sample & $\begin{array}{c}\text { Maximum } \\
\text { Load [N] }\end{array}$ & $\begin{array}{c}\text { Maximum } \\
\text { Stress, [MPa] }\end{array}$ & $\begin{array}{c}\text { Specific } \\
\text { Deformation, } \\
{[\mathbf{m m} / \mathbf{m m}]}\end{array}$ & $\begin{array}{c}\text { Young's } \\
\text { modulus, } \\
{[\mathbf{M P a}]}\end{array}$ \\
\hline 1 & 5781.13 & 58.43 & 0.10 & 1395.75 \\
\hline 2 & 6615.49 & 66.20 & 0.13 & 1385.35 \\
\hline 3 & 6248.27 & 63.56 & 0.12 & 1406.59 \\
\hline 4 & 6425.00 & 66.44 & 0.13 & 1433.80 \\
\hline 5 & 6184.52 & 61.80 & 0.11 & 1394.27 \\
\hline $\begin{array}{c}\text { Mean } \\
\text { Value }\end{array}$ & $\mathbf{6 2 5 0 . 8 8}$ & $\mathbf{6 3 . 2 9}$ & $\mathbf{0 . 1 2}$ & $\mathbf{1 4 0 3 . 1 5}$ \\
\hline $\begin{array}{c}\text { Standard } \\
\text { Deviation }\end{array}$ & $\mathbf{3 1 1 . 5 8}$ & $\mathbf{3 . 3 3}$ & $\mathbf{0 . 0 1}$ & $\mathbf{1 8 . 7 2}$ \\
\hline
\end{tabular}

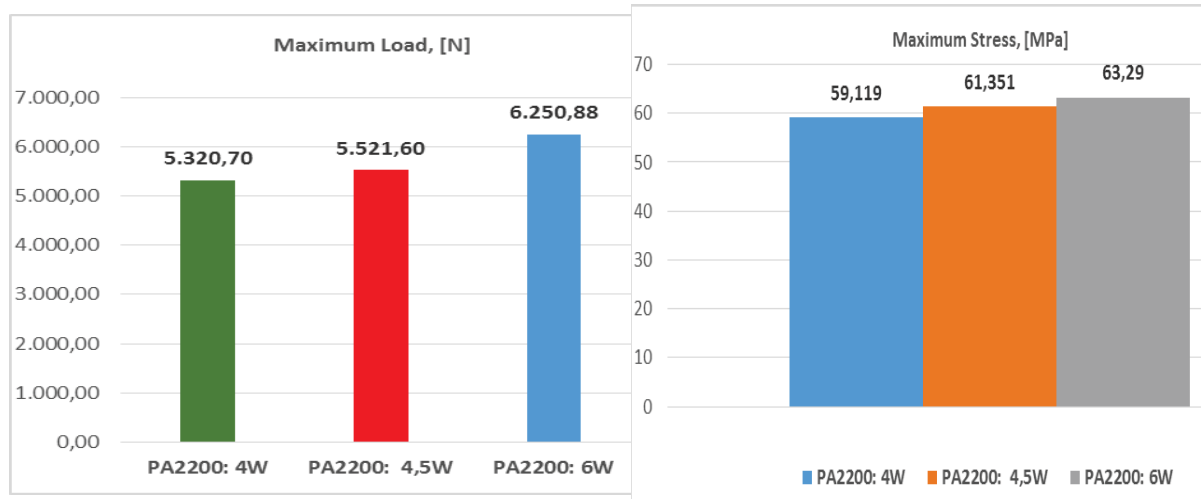

Fig. 4. Mean values of the maximum load and maximum stress for PA 2200 samples at compression tests.

Following the comparative analyse of the mean values obtained at compression test for the PA 2200 samples manufactured at $4 \mathrm{~W}, 4.5 \mathrm{~W}$ and $6 \mathrm{~W}$ (Fig. 2, 3, 4, 5), it was observed that the forces and the stresses have an increasing trend with increasing of the laser power, but the specific deformation is decreasing. This trend can be explained by the structure of the samples achieved by selective laser sintering technology. At the lower laser powers, the 
parts are more porous and at higher laser powers, dense structures can be obtained. By applying forces on the porous structures, the layers are delaminated and a higher value for specific deformation is obtained than in the case of dense structures.

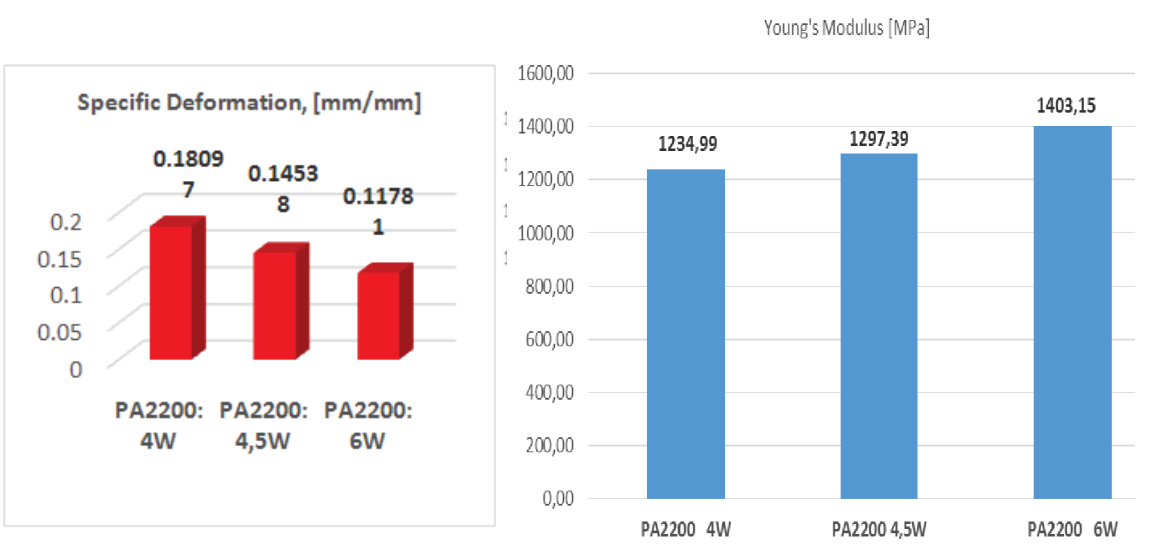

Fig. 5. Mean values of the specific deformation and Young's modulus for PA 2200 samples at compression tests.

Comparing the obtained results with the values for cranial bone from scientific literature, it is important to note that the adult and fetal cranial bones are physically different and have different mechanical properties. According with the research made by [13], the values for the elastic modulus, as a result of quasi-static bending tests, for fetal cranial bone was $3.88 \mathrm{GPa}$ (fibres parallel to specimen long axis) and $0.95 \mathrm{GPa}$ (fibres perpendicular to specimen long axis). The same study reported the elastic modulus of a single calvarium taken from a 6 year old subject as $7.38 \mathrm{GPa}$ (parallel fibres) and 5.86GPa (perpendicular fibres) $[13,17]$.

Other research made by [18] had the objective to evaluate and to compare tissue engineered cell-polymer constructs using calvarial osteoblasts and mesenchymal progenitor cells (MPC) for the reconstruction of critical-size and three-dimensionally complex cranial defects on New Zealand White rabbits. The mechanical investigations for the new grown bone, obtained using tissue engineering revealed that stiffness reached $52 \pm 29$ and $44 \pm 16$ MPa for MPC- and osteoblast-seeded scaffolds, respectively. The yield strength for the push-out tests was $180 \pm 36 \mathrm{~N}$ for normal calvarial bone, $90 \pm 1 \mathrm{~N}$ for unrepaired site, and $106 \pm 10 \mathrm{~N}$ for unseeded constructs, which is about $60 \%$ of normal bone strength. MPCand osteoblast-seeded scaffolds indicated yield strength of $149 \pm 15$ and $164 \pm 42 \mathrm{~N}$, respectively, which is about $85-90 \%$ of normal bone.

The results obtained in the present study, are in the range of the results obtained in the scientific literature.

\section{Conclusions}

Even the powder PA 2200 was manufactured to be used on EOS Sintering Systems, the study proved that this material can be used also for DTM Sinterstation machine if there are used optimal working parameters.

For the bending tests were observed that the results obtained for maximum load, maximum stress, specific deformation and Young's modulus are increasing together with the increasing of the laser power.

In the case of compression test it was showed that once a higher laser power is used in the manufacturing process, better mechanical properties are obtained. The values for the 
forces, stresses and Young's Modulus are higher with the increasing of the laser power and the specific deformation is decreasing when a higher laser power is used.

The mechanical properties obtained at bending and compression tests are in the range of the mechanical properties required for the cranial bone according with the results from the scientific literature.

\section{References}

1. Gr. Adams,Psychological aspects of the facial form craniofacial monographno 11(University of Michigan Press, 1981)

2. R. Tevlin, A. McArdle, D. Atashroo, G.G. Walmsley, K. Senarath-Yapa, E.R. Zielins, K.J. Paik, M.T. Longaker, D.C. Wan, J Dent Res. 93, 12 (2014).

3. M. Mc.Gurk, A. A. Amis, P. Potamianos, N. M. Goodger, Ann R Coll Surg Engl 79,169-174 (1997)

4. Y. Zhang, L. Hao, M. M. Savalani, R. A. Harris, K. E. Tanner, J Biomed Mater Res Part A 86A, 3 (2008).

5. C. K. Chua, K. F. Leong, K. H. Tan, F. E. Wiria, C. M. Cheah, J. Mater. Sci. Mater. Med. 15, 10 (2004)

6. R. Păcurar, A. Păcurar, N. Bâlc, A. Petrilak, L. Morovič, AMM, 371, 478-482 (2013)

7. J. Li, Y. Hsu, E. Luo, A. Khadka, J. Hu, Aesth Plast Surg 35, 636 (2011)

8. B.Caulfield, P.E. Mchugh., S. Lohfeld, J. Mater. Process. Technol. 182, 477-488 (2007)

9. M. Ridzoň, M. Mojžiš, M. Martinkovič. P. Bella, L. Domovcová, L. Parilák, AJME 13, 4 (2015)

10. M. Ridzoň, A. Zavacka, AMM 421, 329-333 (2013)

11. Hubbard R. P.,J Biomech 4, 251-263 (1971)

12. Delille R., Lesueur D., Potier P., Drazetic P., Markiewicz E., Int J Crashworthines 12, 2 (2007)

13. McPherson G. K., Kriewall T. J., J Biomech 13, 9-16 (1980)

14. Margulies S. S., Thibault K. L., J Biomech Eng. 122, 364-371 (2000)

15. Jans G., PhD thesis (KatholiekeUniversiteit Leuven, Belgium, 2003)

16. Coats B., Margulies S., J Neurotrauma 23, 8 (2006)

17. Motherway J. A., Verschueren P.; Van der Perre G., et al, J Biomech 42,13 (2009)

18. J.-T. Schantz, D. W. Hutmacher, C. X. F. Lam, M. Brinkmann, K. M. Wong, T. C. Lim, N. Chou, R. E/ Guldberg, S. H. Teoh, Tissue Eng. 9, 127-139 (2004) 